\title{
Analysis of Multiple Criteria Decision Making Method for Selection the Superior Cattle
}

Analisis Metode Multiple Criteria Decision Making untuk Pemilihan Bibit Sapi Unggul

Received:

13 November 2019

Revised:

30 November 2019

Accepted:

8 December 2019

\author{
${ }^{1 *}$ Lilik Sumaryanti, ${ }^{2}$ Nurcholis \\ ${ }^{1}$ Teknik Informatika, Universitas Musamus \\ ${ }^{2}$ Peternakan, Universitas Musamus \\ ${ }^{1,2}$ Merauke, Indonesia \\ E-mail: ${ }^{1}$ lilik@unmus.ac.id, ${ }^{2}$ nurcholis@unmus.ac.id \\ *Corresponding Author
}

\begin{abstract}
The results of decision making play an important role in achieving a goal in solving certain problems. In the decision making process requires data or supporting evidence that can be used as a guide for the selection of solutions based on available alternatives, so as to produce choices that can increase productivity. MCDM method for the analysis of research data namely AHP, TOPSIS and SMART, the three methods are tested, because each MCDM method has a different way of working or algorithm, so it is necessary to experiment with certain cases. This study aims to determine the performance of the AHP, TOPSIS, and SMART methods with a case study of selecting superior female cattle breeds. The application of three MCDM methods for alternative analysts of prospective superior beef cattle based on testing to determine the accuracy of comparing the results/output of the system with expert recommendation solutions using a sample of 15 female cows that produce priority/ranking for superior beef cattle, shows that the performance of the three methods produces priority selection results the same, with $80 \%$ priority accuracy.
\end{abstract}

Keywords - MCDM, AHP, SMART, TOPSIS

Abstrak - Hasil pengambilan keputusan berperan penting untuk mencapai suatu tujuan dalam penyelesaian masalah tertentu. Dalam proses pengambilan keputusan membutuhkan data atau bukti pendukung yang dapat digunakan sebagai pedoman untuk pemilihan solusi berdasarkan alternatif yang tersedia, sehingga menghasilkan pilihan yang dapat meningkatkan produktivitas. Metode MCDM untuk analisis data penelitian yaitu AHP, TOPSIS dan SMART, pengujian tiga metode tersebut dilakukan, karena setiap metode MCDM memiliki cara kerja atau algoritma yang berbeda-beda, sehingga perlu dilakuka percobaan dengan kasus tertentu. Penelitian ini bertujuan untuk mengetahui kinerja metode AHP, TOPSIS, dan SMART dengan studi kasus pemilihan bibit sapi unggul betina. Penerapan tiga metode MCDM untuk analis alternatif calon bibit sapi unggul berdasarkan pengujian untuk mengetahui akurasi membandingkan hasil/ouput sistem dengan solusi rekomendasi pakar menggunakan sampel 15 sapi betina yang menghasilkan prioritas/ranking untuk bibit sapi unggul, menunjukkan bahwa kinerja ketiga metode tersebut menghasilkan prioritas hasil pemilihan yang sama, dengan akurasi penentuan prioritas $80 \%$.

Kata Kunci-MCDM, AHP, SMART, TOPSIS

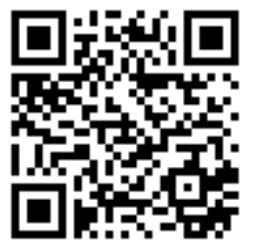


INTENSIF, Vol.4 No.1 February 2020

ISSN: 2580-409X (Print) / 2549-6824 (Online)

DOI: https://doi.org/10.29407/intensif.v4i1.13863

\section{INTRODUCTION}

Decision making is an activity that has an essential role in achieving a specific goal, based on the selection of several available alternatives, in producing a final choice that uses a particular analysis approach or method. Decision making is a recursive process that involves several decision criteria, a Decision Support System (DSS) appears to help decision-makers in the decision making the process [1]. The decision support system is an application that is used as a tool for evidence-based decision making in agriculture [2] [3]. Decision support tools function to provide the best alternative information related to a particular case problem to act more appropriately to increase productivity [4]. To support the evaluation and selection process, formal decision-making methods can be used using the Multiple Criteria Decision Making (MCDM) method [5]. The application of decision support systems is used for the selection of electricity experts based on competency tests which are implemented by comparing several Multi-attribute Decision Making (MADM) methods [6]. Decision making by MCDM method aims to find the best alternative of all alternatives [4].

The use of the MCDM method is used for data analysis so that it can produce the best alternative recommendations based on the criteria used for the selection or selection process. Each MCDM method has a different way of working or algorithm, so it is necessary to experiment in some instances to find out the method that can recommend the best alternative by comparing the results of recommendations with alternative solutions from experts. The research aims to determine the performance of several MCDM methods including Analytic Hierarchy Process (AHP), Technique for Order Preference by Similarity to Ideal Solution (TOPSIS), and Simple Multi-Attribute Rating Technique (SMART). The system for prioritising the selection of improved government asset management by applying the AHP and TOPSIS methods, testing with an accuracy rate of $83 \%$ [7]. The results of decision making using the AHP method compared to the TOPSIS Method, show that there are inconsistencies in the sample data, i.e. some matrices in the data have a consistency ratio of more than 0.1 , resulting in different alternative ranks [8].

This research uses a case study on the selection of superior female cattle breeds, with the criteria used for data analysis using national standards for selecting good beef cattle breeds [9]. Provision of beef production to meet needs must support the availability of 
INTENSIF, Vol.4 No.1 February 2020

ISSN: 2580-409X (Print) / 2549-6824 (Online)

DOI: https://doi.org/10.29407/intensif.v4i1.13863

good quality beef cattle. Cows are cattle that have superior physical and kinetic properties that can be inherited, as well as meeting the requirements for breeding with excellent reproductive performance. The selection process for the quality of beef cattle sees from various aspects, including body size/morphology and physical condition.

\section{RESEARCH METHOD}

The research phase carries out to conduct a comparative analysis of the results of the performance of several MCDM methods including AHP, SMART and TOPSIS with a case study of selecting superior breeds of female cows to be bred. Stages of the implementation of research activities are in the research flow chart Figure 1.

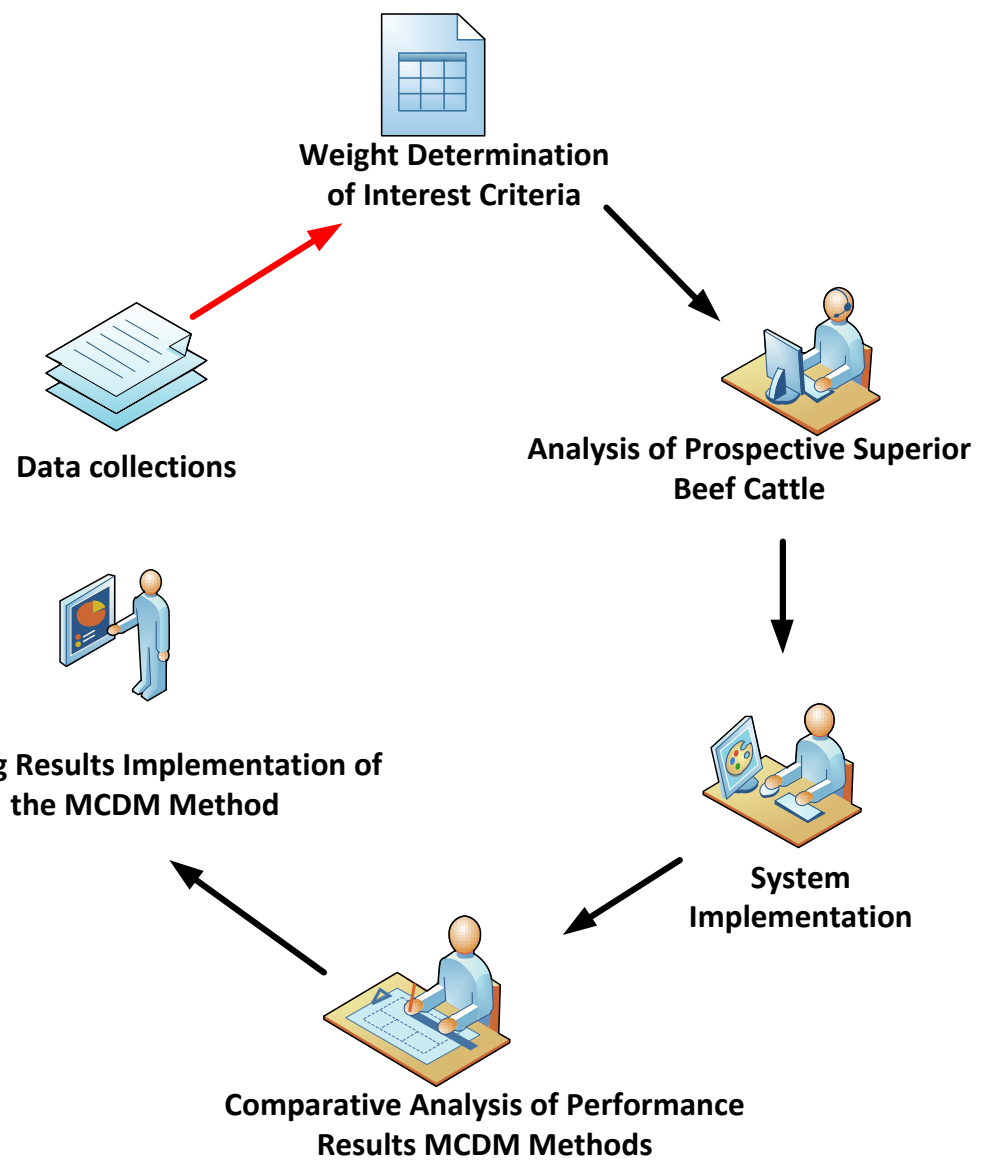

Figure 1. RESEARCH StAge DiAgRAM BLOCK

The stages of the research activities in Figure 1 explain as follows:

Data Collection is the process of finding information needed to support the implementation of research objectives. The information required is related to the research, namely: prospective beef cattle breeders data, namely using Ongole breeding cows (PO), criteria for the selection of beef cattle breeds, methods or procedures carried out by experts in determining beef cattle 
INTENSIF, Vol.4 No.1 February 2020

ISSN: 2580-409X (Print) / 2549-6824 (Online)

DOI: https://doi.org/10.29407/intensif.v4i1.13863

breeds, national standards for selecting cow breeds and guidelines for choosing good cattle breeds, the method used to collect research data through literature studies, interviews, field observations.

The determination of the weight of importance for each criterion is based on three MCDM methods, namely AHP, SMART and TOPSIS methods. This stage is to determine the priority interests of the requirements for the selection of superior cattle breeds that will be used for the next phase of research.

Data analysis of prospective superior cattle breeds is an activity of measuring the sample of research data by applying the AHP, SMART and TOPSIS method algorithms. At this stage, it will produce a ranking for all alternative solutions for superior beef cattle seeds recommended, so that it can be known classification (priority) of each alternative solution that is as information in the decision-making process.

System Implementation is a process of testing the system that has developed to find out whether the results/outputs of the system have met the information needs of the system user. System Testing to measure/find out the truth of alternative solutions recommended by the system, to find out the accuracy of comparing the results/output of the system with expert recommendation solutions.

The application of the three MCDM method algorithms namely AHP, SMART and TOPSIS, begins with a list of criteria that used for the selection of superior beef cattle by the guidelines for selecting good beef cattle for the Indonesian National Standard (SNI).

HP method applied is to solve problems by structuring a hierarchy of criteria, alternative outcomes to be the goal, by determining the weight or priority interests of each standard for each alternative [10]. The initial stage of the AHP method begins with structuring the problem into a hierarchy and then evaluating the components with a paired comparison matrix. The objectives are placed in the authority at the top level, while the criteria and sub-criteria are at the middle level; alternatives are at the lowest level [11] — comparison of paired matrices with a scale value of one to nine used for all criteria and options. Then we determine the weights for each standard, and all local weights for each criterion calculate to obtain the global weights for all other options [12]. Check the index consistency value (CI) using equation 1.

$$
C I=\frac{y_{\max }-n}{n-1}
$$

The process of calculating the consistency ratio value $(\mathrm{CR})$ is done as the final stage of analysis by the AHP method, if the ratio consistency value $<=0.1$, so that it can proceed to the next stage. If on the contrary, the determination of the importance of the criteria and the calculation process. The analysis using the AHP method must be repeated. Calculation of ratio consistency using equation 2 


$$
C R=\frac{C I}{I R}
$$

$$
\begin{aligned}
& \text { Information }: \\
& C R=\text { Consistency Rasio } \\
& C I=\text { Consistency Index } \\
& I R=\text { Index Random Consistency }
\end{aligned}
$$

The SMART method is one of the methods used in data analysis that supports multi-criteria decision making, meaning that each alternative has a criterion value with a certain weight. Analysis using the SMART way is based on a linear additive model. It shows that the total amount of the specified alternatives will be used to calculate the overall performance score of each criterion with a predetermined weight, which will be multiplied by the standards weight. The steps for implementing the SMART method are explained as follows [13]. Determination of utility begins by converting the criterion value of each alternative using equation following equation 3

$$
u_{i}\left(a_{i}\right)=\frac{c_{\text {out }}-c_{\min }}{c_{\max }-c_{\min }}
$$

Utilities for each alternative are obtained using equation 4

$$
u\left(a_{i}\right)=\sum_{j=1}^{m} w_{j} u_{i}\left(a_{i}\right)
$$

Utility value shows the result of the analysis process using the SMART method. The final step is the selection of superior breed cattle by alternative ordering process with the largest to the smallest utility [14].

The TOPSIS algorithm guides the process of calculating the selected alternative is the best of all available options, which has the shortest distance from the positive ideal solution, and the choice also has the most extended range from the perfect negative solution [15]. The positive ideal solution is a calculation of all the best values achieved by each criterion, while the ideal negative solution is the opposite of the worst possible value. The TOPSIS method uses both as an alternative measurement to choose to calculate the distance to the positive ideal solution and the distance to the negative ideal solution by selecting the proximity relative to the positive ideal solution [16].

Determination of the distance and criterion value of each alternative to the positive ideal solution, and the negative ideal solution based on equation 5 .

$$
\begin{aligned}
& A^{+}=\left(y_{1}{ }^{+}, y_{2}{ }^{+}, y_{3}{ }^{+}, \ldots, \ldots, y_{m}{ }^{+}\right) \\
& A^{-}=\left(y_{1}{ }^{-}, y_{2}{ }^{-}, y_{3}{ }^{-}, \ldots, \ldots, y_{n}{ }^{-}\right) \\
& D_{i}^{+}=\sqrt{\sum_{j=1}^{n}\left(y_{i}{ }^{+}-y_{i j}\right)^{2}} ; \quad i=1,2, \ldots, m .
\end{aligned}
$$


INTENSIF, Vol.4 No.1 February 2020

ISSN: 2580-409X (Print) / 2549-6824 (Online)

DOI: https://doi.org/10.29407/intensif.v4i1.13863

$$
D_{i}^{-}=\sqrt{\sum_{j=1}^{n}\left(y_{i j}-y_{i}{ }^{-}\right)^{2}} ; \quad i=1,2, \ldots, m
$$

The practical steps of the three MCDM methods for the analysis of research data are shown in Figure 2.

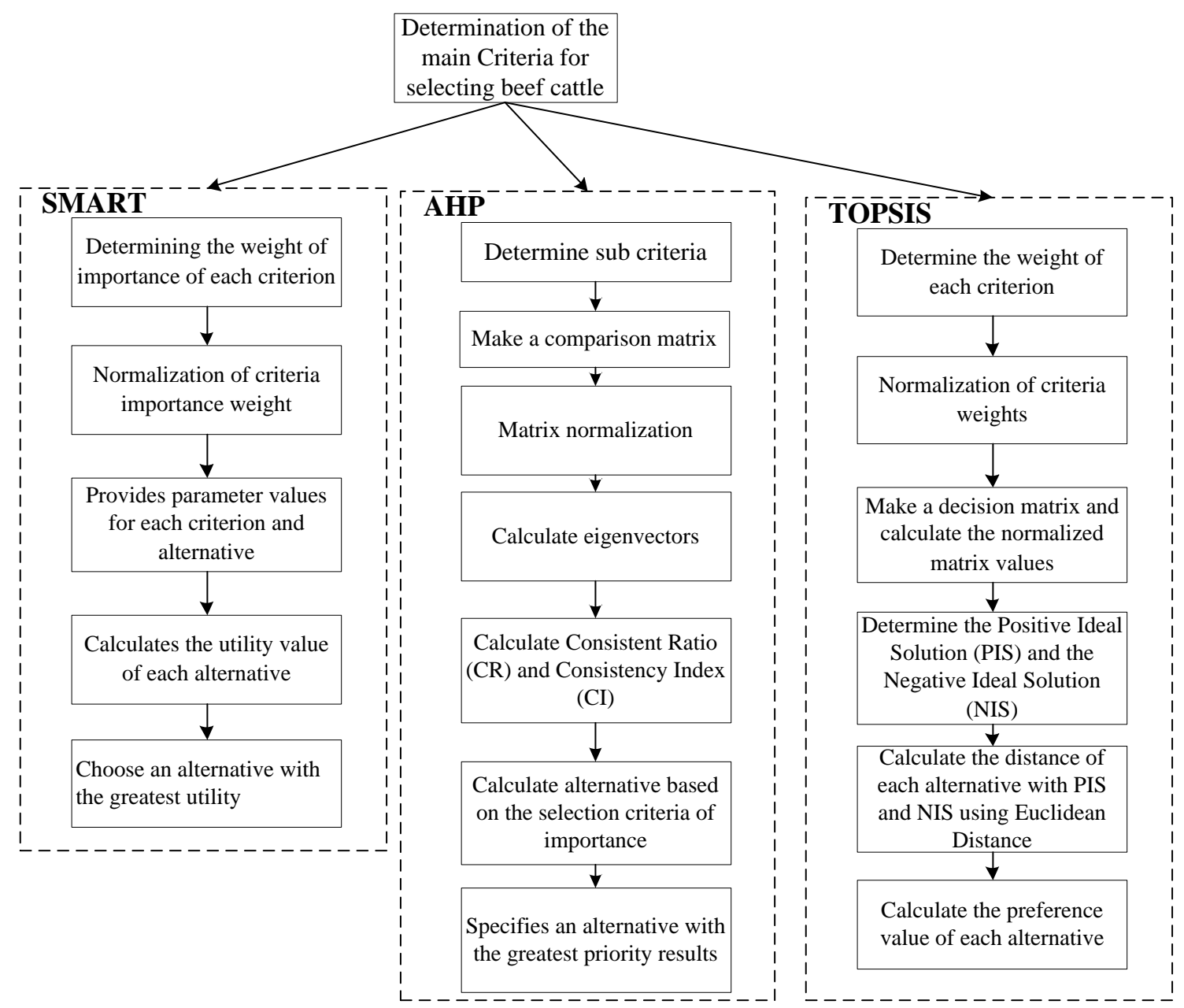

Figure 2. AHP WORKING STEPS, TOPSIS DAN SMART

\section{RESULT AND DISCUSSION}

Multi-criteria analysis for decision support systems including AHP, SMART and TOPSIS methods through the Multiple-Criteria Decision-Making (MCDM) approach has been developed, including the decision making to review papers that have been distributed based on specific publishing periods on Thomson's Web Core Science Collection [17]. The use of particular methods for data analysis to support decision making is one of the steps undertaken to produce relevant and evidence-based information for decision-makers, thus enabling its users to accept the suggestions generated by the system [18]. 
INTENSIF, Vol.4 No.1 February 2020

ISSN: 2580-409X (Print) / 2549-6824 (Online)

DOI: https://doi.org/10.29407/intensif.v4i1.13863

The hierarchy in Figure 3, shows the relationship between objectives, criteria and alternatives in AHP. The next stage after the compilation of the hierarchy is, determine alternative values and standards, check the consistency of pairwise comparison matrix ratios to assess alternatives and measures, determine priority criteria

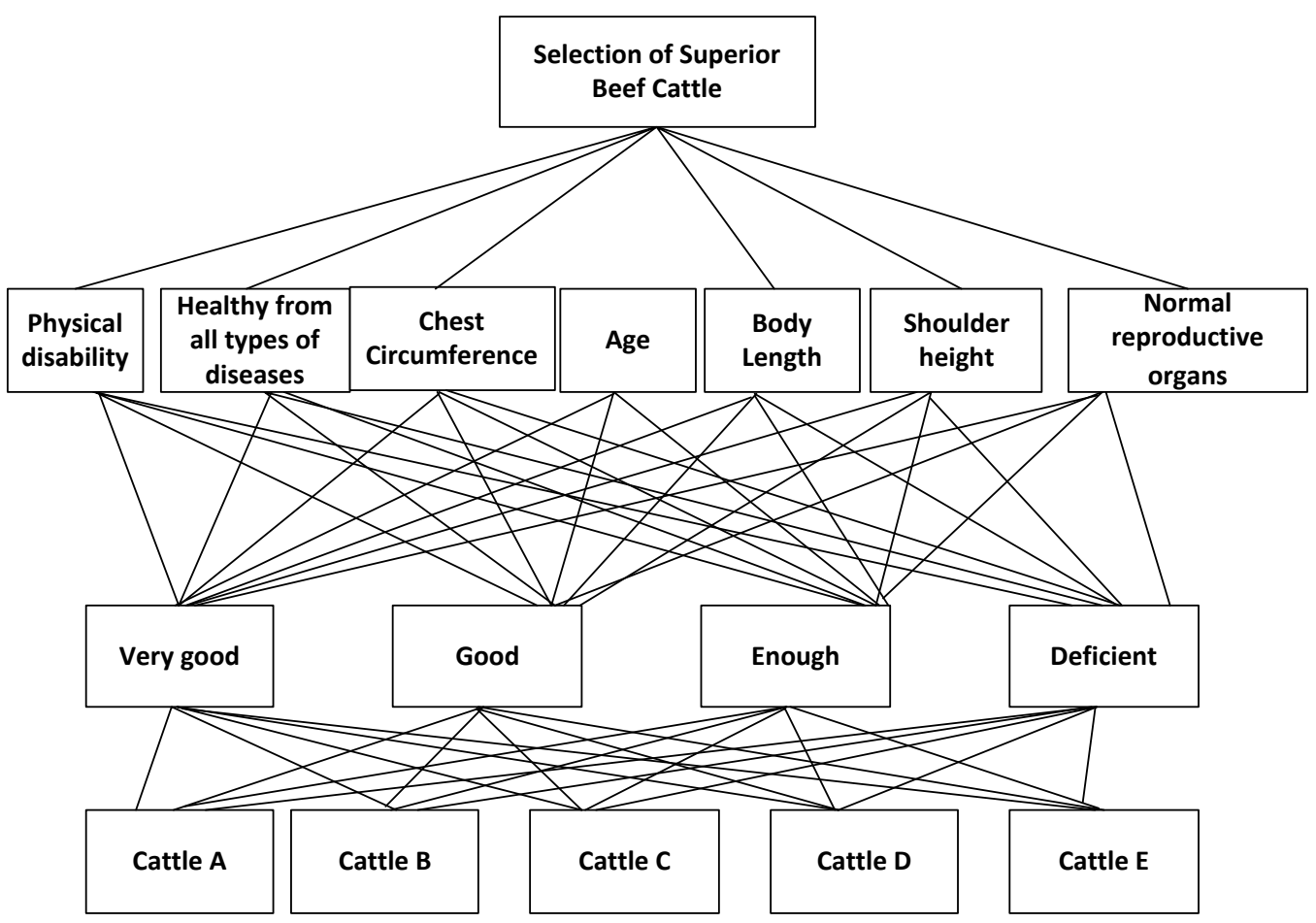

Figure 3. HIERARCHY OF SELECTION OF SUPERIOR BREEDS OF CATTLE

A list of standards used for selecting superior breeds of female cows is shown in Table 1.

Table 1. CRiteria SELECTION Of SuPERIOR BREEDS OF FEMALE COWS

\begin{tabular}{ll}
\hline \hline No & \multicolumn{1}{c}{ Criteria } \\
\hline 1 & Healthy and free from all animal diseases \\
\hline 2 & $\begin{array}{l}\text { Livestock do not have physical defects and reproductive } \\
\text { organs }\end{array}$ \\
\hline 3 & Female ongol crossbreed cattle have udders and healthy \\
& reproductive organs \\
\hline 4 & Age of Cow (month) \\
\hline 5 & Tern Height (cm) \\
\hline 7 & Body Length Size $(\mathrm{cm})$ \\
\hline
\end{tabular}

Measurement of the accuracy of the performance of each MCDM method depends on the results of the analysis of the application of three methods compared with the results of alternative 
INTENSIF, Vol.4 No.1 February 2020

ISSN: 2580-409X (Print) / 2549-6824 (Online)

DOI: https://doi.org/10.29407/intensif.v4i1.13863

solution recommendations from experts. The results of the performance of the AHP, SMART and TOPSIS methods are shown in Table 2.

Table 2. COMPARISON OF SYSTEM RESULTS AND EXPERT RECOMMENDATIONS

\begin{tabular}{ccccc}
\hline $\begin{array}{c}\text { Alternative } \\
\text { Rank }\end{array}$ & AHP & SMART & TOPSIS & PAKAR \\
\hline 1 & Sapi H & Sapi H & Sapi H & Sapi H \\
\hline 2 & Sapi B & Sapi B & Sapi B & Sapi D* \\
\hline 3 & Sapi D & Sapi D & Sapi D & Sapi E* \\
\hline 4 & Sapi E & Sapi E & Sapi E & Sapi B* \\
\hline 5 & Sapi C & Sapi C & Sapi C & Sapi C \\
\hline 6 & Sapi O & Sapi O & Sapi O & Sapi O \\
\hline 7 & Sapi K & Sapi K & Sapi K & Sapi K \\
\hline 9 & Sapi A & Sapi A & Sapi A & Sapi A \\
\hline 10 & Sapi L & Sapi L & Sapi L & Sapi L \\
\hline 11 & Sapi N & Sapi N & Sapi N & Sapi N \\
\hline 12 & Sapi M & Sapi M & Sapi M & Sapi M \\
\hline 13 & Sapi F & Sapi F & Sapi F & Sapi F \\
\hline 14 & Sapi I & Sapi I & Sapi I & Sapi I \\
\hline 15 & Sapi G & Sapi G & Sapi G & Sapi G \\
\hline & Sapi J & Sapi J & Sapi J & Sapi J \\
\hline & & & &
\end{tabular}

The experiment conducted using a sample data of fifteen cows which are prospective superior breeders for the process of selecting the best alternative superior breeders. The results of the selection by applying the AHP, SMART and TOPSIS methods in the form of priority values (alternative ranking) are shown in Table 2 . The test is carried out by a scenario comparing the results of ranking superior seeds for five female cows with the determination of ranking results from experts, which shows differences for alternative ranks 2, 3 and 4. Measurement accuracy based on test scenarios for the three methods is explained as follows:

$$
\begin{aligned}
& \text { Akurasi AHP }=\frac{12}{15} \times 100 \%=80 \% \\
& \text { Akurasi SMART }=\frac{12}{15} \times 100 \%=80 \%
\end{aligned}
$$


Akurasi TOPSIS $=\frac{12}{15} \times 100 \%=80 \%$

The results of testing the three methods have the same performance in the analysis for the selection of superior cattle breeds. The accuracy of the effects of comparison with expert predictions is $80 \%$. Figure 4 shows an example of the results of application development for the analysis of research data using AHP.

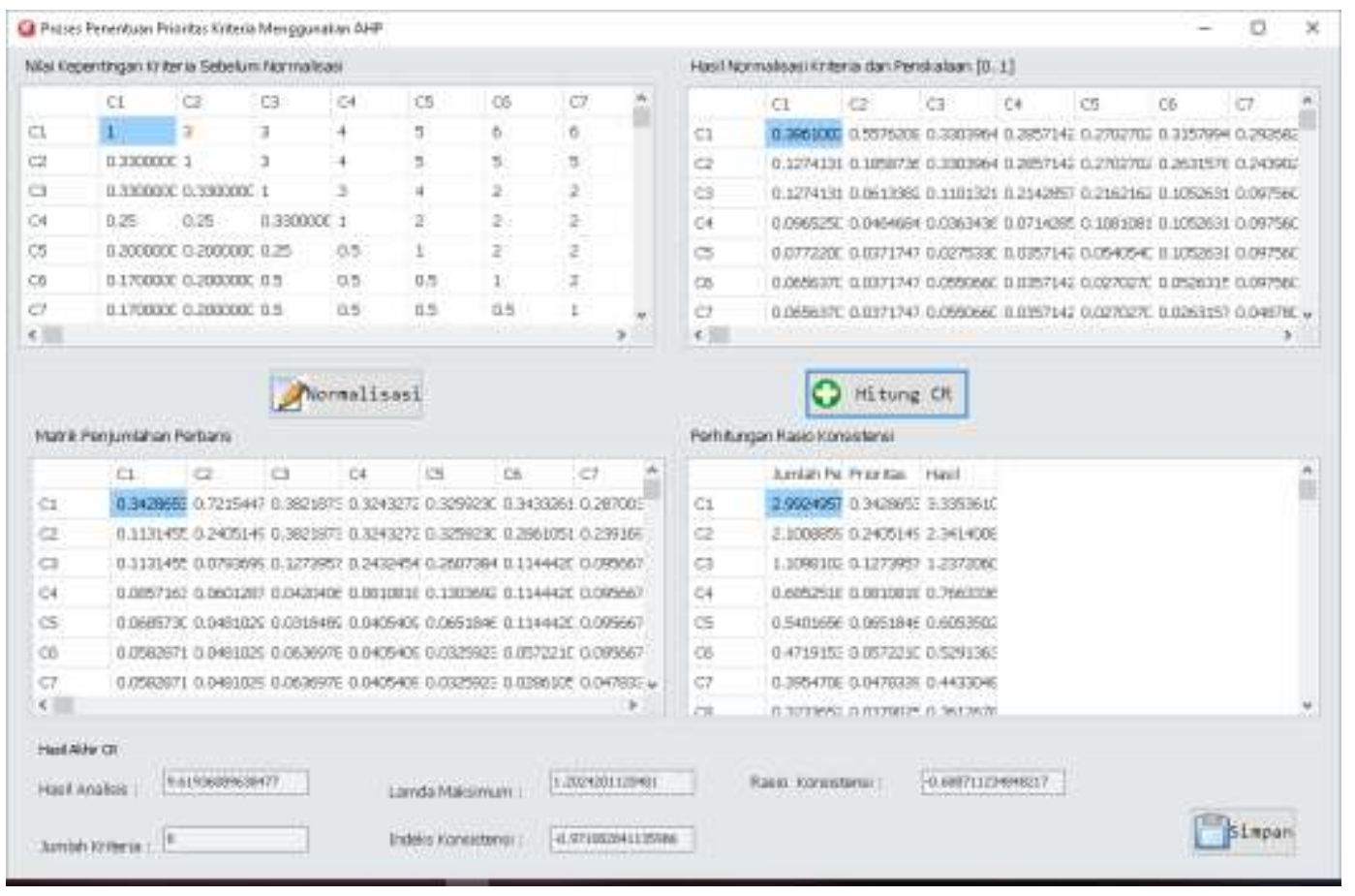

Figure 4. AHP METHOD IMPLEMENTATION

The AHP method works to solve complex problem domains, making it ideal for dealing with problems by comparing performance among alternatives. But if it is implemented on an issue, with other options always increasing, it's best to avoid using this method. The advantages of AHP, easy to use, the hierarchical structure can easily adjust according to the size of the number of problems. The weakness of this method is that there is interdependence between criteria and alternatives, and can lead to inconsistencies between the evaluation of criteria and ranking. The application of AHP generally used for the problem of determining the type of performance, the selection and management of human resources, the determination of public policies, political strategies, the decision of company policies and strategy and planning. One application of the AHP method for site selection, to provide information related to the development plan for the location of health infrastructure [18]. The results of the analysis using the SMART method has the advantage of being easy to use, allowing for the use of all types of weight determination techniques, e.g. relative, absolute, easy to obtain information access to decision-makers. The implementation of SMART finds in applications related to environmental, construction, 
INTENSIF, Vol.4 No.1 February 2020

ISSN: 2580-409X (Print) / 2549-6824 (Online)

DOI: https://doi.org/10.29407/intensif.v4i1.13863

transportation, logistics, military, manufacturing and assembly issues. Whereas the TOPSIS method has the advantage of a simple, easy to use and programmed algorithm implementation process, the number of steps remains the same regardless of the number of attributes, the weakness of this method is: the use of euclidean distance does not consider attribute correlations, making it difficult to maintain consistency of judgment. Typical applications for supply chain and logistics management issues, manufacturing systems, business and marketing, environment, human resources, and water resource management.

\section{CONCLUSSION}

The application of three MCDM methods for the case of selecting superior breeds of female cows shows that the performance of the three methods produced the same alternative recommendations in the experiments that have been carried out, despite having different algorithms and ways of working, with an accuracy level of $80 \%$.

\section{AKNOWLEGMENT}

The researcher would like to thank the Management and staff at the Ministry of Research Technology and Higher Education who have funded this research.

\section{REFERENCE}

[1] C. S. Wang, H. L. Yang, and S. L. Lin, "To Make Good Decision: A Group DSS for Multiple Criteria Alternative Rank and Selection," Math. Probl. Eng., vol. 2015, pp. 1$15,2015$.

[2] E. Kerselaers, E. Rogge, L. Lauwers, and G. Van Huylenbroeck, "Decision support for prioritising of land to be preserved for agriculture: Can participatory tool development help?," Comput. Electron. Agric., vol. 110, pp. 208-220, 2015.

[3] I. Kaya and C. Kahraman, "A comparison of fuzzy multicriteria decision-making methods for intelligent building assessment," J. Civ. Eng. Manag., vol. 20, no. 1, pp. 59-69, 2014.

[4] L. Sumaryanti, L. Lamalewa, and T. Istanto, "Implementation Of Multiple Fuzzy Criteria Decision Making For Recommendation Paddy Fertilizer," Int. J. Mech. Eng. Technol., vol. 10, no. 3, pp. 236-243, 2019.

[5] E. K. Zavadskas, J. Antucheviciene, Z. Turkish, and H. Adeli, "Hybrid multiple-criteria decision-making methods: A review of applications in engineering," Sci. Iran., vol. 23, no. 1, pp. 1-20, 2016.

[6] A. Papadopoulos, D. Kalivas, and T. Hatzichristos, "Decision support system for nitrogen fertilisation using fuzzy theory," Comput. Electron. Agric., vol. 78, pp. 130-139, 2011.

[7] J. Febriansyah, R. Gernowo, and A. Kusumawardhani, "Implementation of AHP and TOPSIS Method to Determine the Priority of Improving the Management of Government's Assets," Int. J. Innov. Res. Adv. Eng., vol. 4, no. 3, pp. 46-53, 2017.

[8] S. Supraja and P. Kousalya, "A comparative study by AHP and TOPSIS for the selection of all-round excellence award," Int. Conf. Electr. Electron. Optim. Tech., pp. 314-319, 2016.

[9] S. Nasional, I. Ics, and B. S. Nasional, Bibit sapi Potong - Bagian 5: Peranakan Ongole. 
Jakarta, 2015.

[10] L. Sumaryanti, T. K. Rahayu, A. Prayitno, and Salju, "Comparison study of SMART and AHP method for paddy fertiliser recommendation in decision support system Comparison study of SMART and AHP method for paddy fertiliser recommendation in the decision support system," IOP Conf. Ser. Earth and Environ. Sci., pp. 1-5, 2019.

[11] M. M. D. Widianta, T. Rizaldi, D. P. S. Setyohadi, and H. Y. Riskiawan, "Comparison of Multi-Criteria Decision Support Methods (AHP, TOPSIS, SAW \& PROMENTHEE) for Employee Placement," J. Phys. Conf. Ser., pp. 1-5, 2017.

[12] J. Thor, S. Ding, and S. Kamaruddin, "Comparison of Multi-Criteria Decision Making Methods From The Maintenance Alternative Selection Perspective," Int. J. Eng. Sci., vol. 2, no. 6, pp. 27-34, 2013.

[13] M. B. Barfod and S. Leleur, Multi-criteria decision analysis for use in transport decision making. 2014.

[14] D. Siregar, D. Arisandi, A. Usman, D. Irwan, and R. Rahim, "Research of Simple MultiAttribute Rating Technique for Decision Support," J. Phys. Conf. Ser., pp. 1-6, 2017.

[15] S. Gurung and R. Phipon, "Multi-criteria decision making for supplier selection using AHP and TOPSIS method," Int. J. Eng. Invent., vol. 6, no. 2, pp. 13-17, 2016.

[16] M. Bartolozzi, P. Bellini, P. Nesi, G. Pantaleo, and L. Santi, "A smart decision support system for smart city," Proc. - 2015, pp. 117-122, 2015.

[17] V. Patil, S. Payer, T. Teli, and S. Jaychandran, "Decision Support System for Agriculture Management," Int. J. Emerg. Trends Sci. Technol., vol. 3, no. 2, pp. 3505-3508, 2016.

[18] M. Velasquez and P. T. Hester, "An Analysis of Multi-Criteria Decision Making Methods,” Int. J. Oper. Res., vol. 10, no. 2, pp. 56-66, 2013. 